\title{
THE EFFECT OF THE APPLICATION OF THE EXACT AND APPROXIMATE METHODS ON VALUES OF SELECTED ECOLOGICAL INDICES
}

\author{
Maria Ługowska, Zofia Rzymowska \\ Department of Agricultural Ecology University of Natural Sciences and Humanities \\ B. Prusa 14, 08-110 Siedlce, Poland \\ e-mail: ekorol@uph.edu.pl
}

Received: 30.03.2013

\begin{abstract}
The work presents the results of a study on the biodiversity of agrocenoses using ecological indices. In order to calculate the measures, phytosociological relevés were made and exact methods were applied in winter cereals, spring cereals, tuber crops and stubble fields. The objective of the work was to compare ecological indices (Simpson's index of dominance $C$, Simpson's index of species richness $D$, and Shannon-Wiener index of biodiversity $H^{\prime}$ ) calculated using the number of plants and their cover determined based on the degree of presence. Moreover, correlation analysis was conducted between the indices computed using the two approaches applied.

The results of the study revealed significant differences between all the indices calculated using the exact and approximate methods. In turn, comparisons of the measures computed for individual crops showed significant differences only for potato crops and winter cereals. No significant differences were found between the indicators calculated for spring cereals and stubble fields.
\end{abstract}

Key words: index of dominance, index of species richness, index of biodiversity, comparison, agricultural crops.

\section{INTRODUCTION}

Withdrawal of the most vulnerable components of nature contributes to a decline in biological diversity $[1,2]$. This phenomenon makes it necessary to search for ways and methods to effectively monitor these changes.

Evaluation of biodiversity in ecological studies is usually made at the species level because quantitative and qualitative changes reflect the state of the environment. They are the focus of many ecological studies examining forest, meadow, field and waterside vegetation and evaluating nutrient status and water contamination levels [3-6].

Over the last decades, segetal communities have undergone substantial changes due to marked agricultural production intensification which can reduce or stimulate biodiversity in cultivated fields. It is common knowledge that the more diverse species composition of a community, the less threat it poses [7-9]. Diversity of agrocenoses depends on species richness as well as number of plants and reciprocal quantitative proportions between the species.

In order to better capture species diversity in agricultural crops, ecological indices are more and more frequently used to analyze weed communities. In ecological studies on plant communities, many scientists use the Shannon-Wiener index of biodiversity and Simpson's index of dominance to assess species richness and reciprocal relationships between species [6,10-12]. These measures are calculated using a quantitative gravimetric method based on numbers of individual species or their biomass. In turn, indices calculated in the classical Braun-Blanquet method are based on cover. The application of the exact method is very time-consuming.

Comparison of these indicators computed using both the aforementioned methods based on research conducted in the same location will make it possible to determine the relation between the indicators and answer the question as to the extent of similarity between the results obtained by means of the two methods applied.

There is a lack of papers comparing the indices calculated using both the aforementioned methods relative to segetal communities.

The aim of this study is to make comparisons of values of ecological indices (Simpson's index of 
dominance $C$, Simpson's index of species richness $\mathrm{D}$, and Shannon-Wiener index of biodiversity $H^{\prime}$ ) computed based on the exact and approximate methods.

\section{MATERIALS AND METHODS}

This study was conducted in the years 2010 2012 in private agricultural holdings where traditional farming methods were used. The farms were located

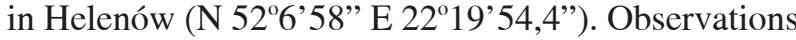
were made in potato crops, winter cereals (triticale), spring cereals (a mixture of spring cereals), and in stubble fields. The soils represent either a very good or good class of agricultural land suitability. Analysis of dominant species of the cropped land has been presented in a previous paper [13]. Thirty observations were made for each crop group. To calculate all the indices, we used:

- phytosociological relevés taken using the widely applied Braun-Blanquet method from an area of $25 \mathrm{~m}^{2}$, in the approximate method;

- in the exact method, a $1 \times 0.5 \mathrm{~m}$ quadrat was thrown twice to fall at random and the results obtained were added up to produce a composite sample. Observations by this method were made at the place where the phytosociological relevé was made.

The comparison of the values of the indices in the exact method was based on the number of individual species, whereas the approximate method made use of the cover ratings of the Braun-Blanquet scale (+ - $0.1 ; 1-5 ; 2-17.5 ; 3-37.5 ; 4-62.5 ; 5-87.5)$ [14].

The ecological indices were computed with the PAST package. Next, they were statistically verified by means of the Statistica package. The values of the indicators (Simpson's index of dominance $C$, Simpson's index of species richness $D$, and Shannon-Wiener index of biodiversity $H^{\prime}$ ) calculated using both the methods were compared by means of the independent samples $\mathrm{T}$ test. One-way analysis of variance was carried out to investigate the effect of crop plants on the difference between means. Correlation coefficients were computed to investigate relationships between the indices for individual crops according to the methods applied.

\section{RESULTS}

This work presents the results of the study comparing the values of ecological indices that were calculated using the two methods. The values of Simpson's index of dominance $C$, Simpson's index of species richness $D$, and Shannon-Wiener index of biodiversity $H^{\prime}$ calculated for all the crops based on the two methods examined differed significantly. Higher $D$ and $H^{\prime}$ values were obtained when the indices were computed based on the number of weeds, whereas Simpson's index of dominance was relatively lower compared with the cover-based counterpart (Fig. 1). The calculated coefficient of correlation indicated that there was a weak relationship between all the indices computed for all the crops using both the methods (Table 1).

The values of the diversity measures studied differed depending on crop plants. Analysis of Simpson's index of dominance for individual crops revealed significant differences for winter cereals and tuber crops, whereas for spring cereals and stubble fields they were insignificant (Fig. 2). The correlation between these indices was significant and positive for winter cereals and tuber crops when calculated based on the approximate method (Table 1).

The mean values of the dominance index for winter cereals and tuber crops were respectively 0.25 and 0.29 when calculated by the exact method, while for the approximate method they were respectively 0.45 and 0.48 (Fig. 2).

Similar results were observed for Simpson's index of species richness $(D)$, as significant differences were found for winter cereals and tuber crops (Fig. 3). When this measure was computed using the approximate method, it was negatively correlated with the exact method (Table 1). The mean $D$ values for winter cereals and tuber crops were, respectively, 0.74 and 0.71 for the exact method, while for the approximate method 0.55 and 0.52 (Fig. 3).

The relationships observed for $\mathrm{D}$ were also found in the case of the index of biodiversity ( $\left.H^{\prime}\right)$ (Fig. 4): the lowest values, 1.2 for winter cereals and 1.1 for tuber crops, were obtained when calculated based on the approximate method. Much higher values were for the exact approach: 1.78 and 1.62, respectively (Fig. 4).

Table 1

Values of correlation coefficients between the analyzed indices by calculation method and crop

\begin{tabular}{lccc}
\hline \multicolumn{1}{c}{ Crop groups } & $\mathrm{C}$ & $\mathrm{D}$ & $\mathrm{H}^{\prime}$ \\
\hline Potato crops & $0.5030^{*}$ & $-0.5030^{*}$ & $-0.5531^{*}$ \\
Winter crops & $0.4942^{*}$ & $-0.4942^{*}$ & $0.5856^{*}$ \\
Spring crops & 0.1254 & -0.1254 & -0.0093 \\
Stubble field & -0.1899 & 0.1899 & 0.0657 \\
All crop groups & $0.2324^{*}$ & $-0.2324^{*}$ & $-0.2635^{*}$ \\
\hline
\end{tabular}

* significant at $\mathrm{p}<0.05$ 

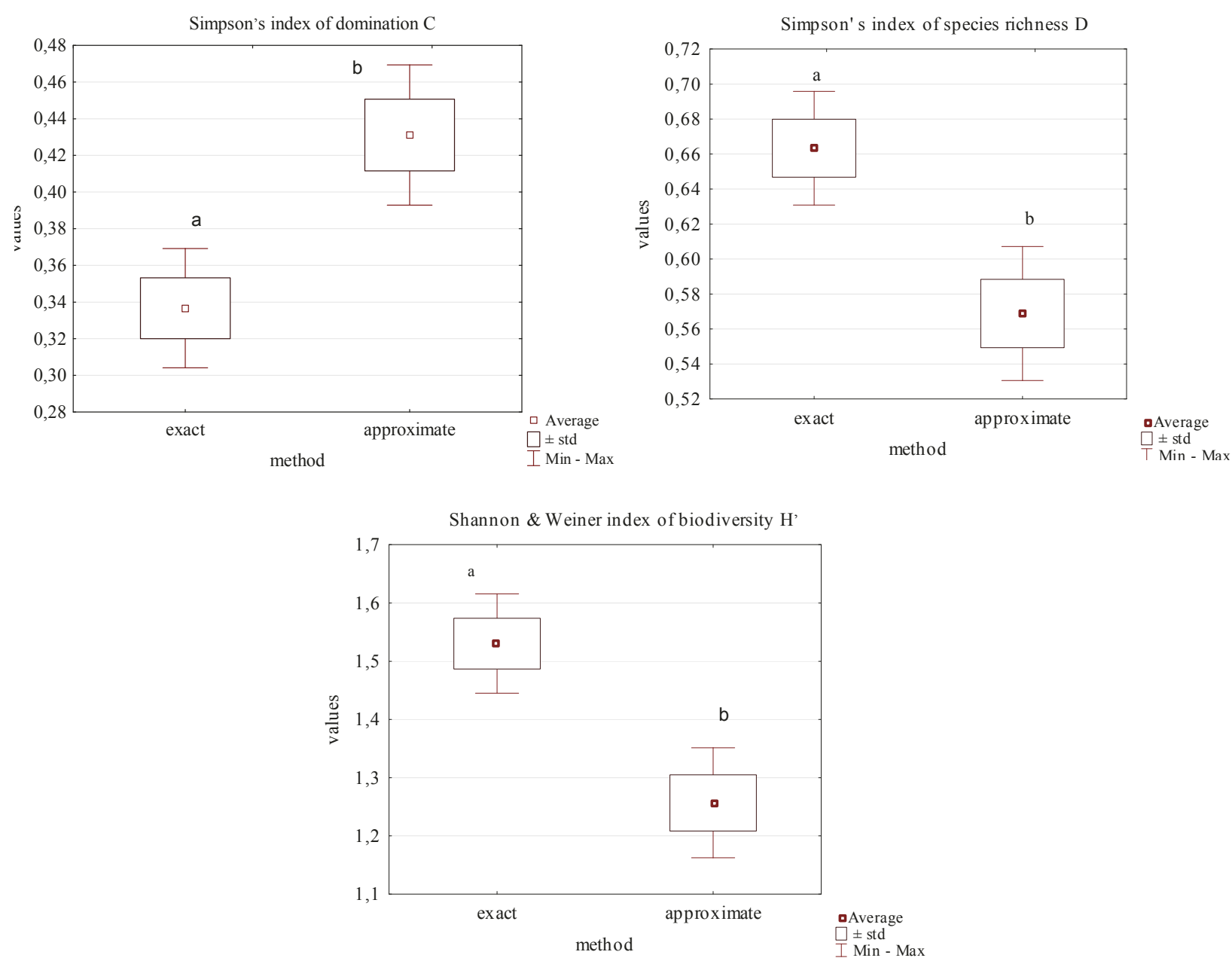

Explanations: $\mathrm{ab}$ - significant at $\mathrm{p}<0.05$

Fig. 1. Values of diversity indices by calculation method

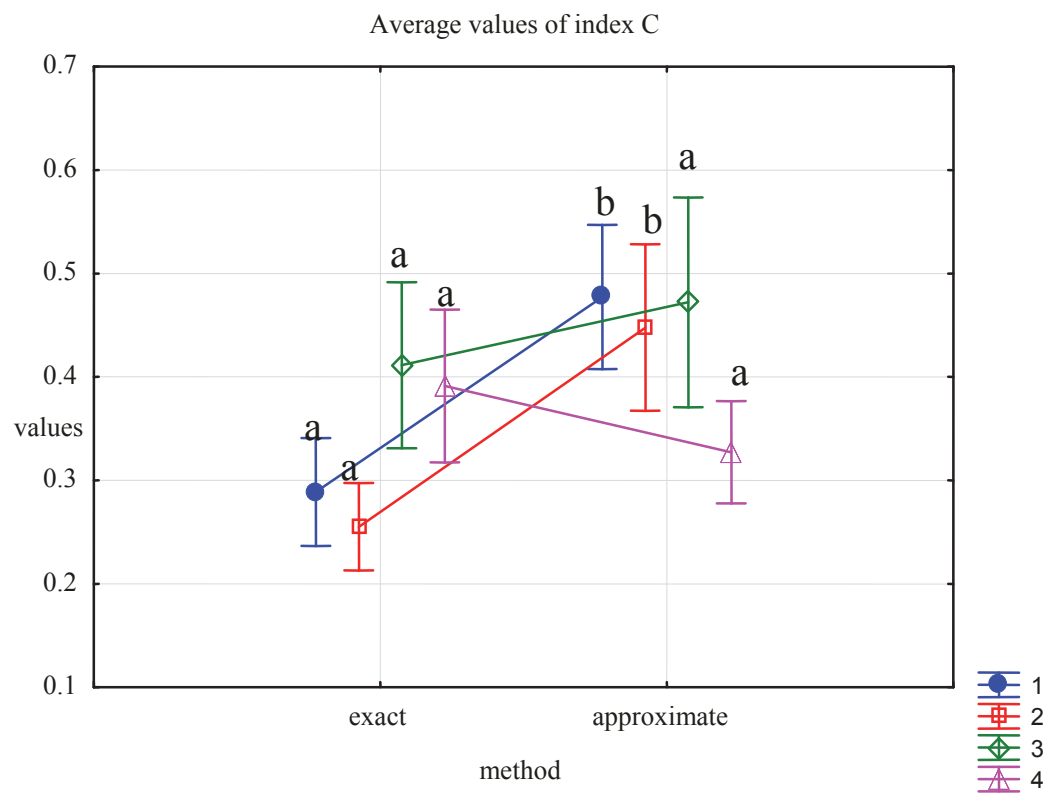

Explanations: 1 - potato crops, 2 - winter crops, 3 - spring crops, 4 - stubble fields, ab - significant at $\mathrm{p}<0.05$

Fig. 2. Simpson's indices of species richness (C) by calculation method and crop studied 
Average values of index D

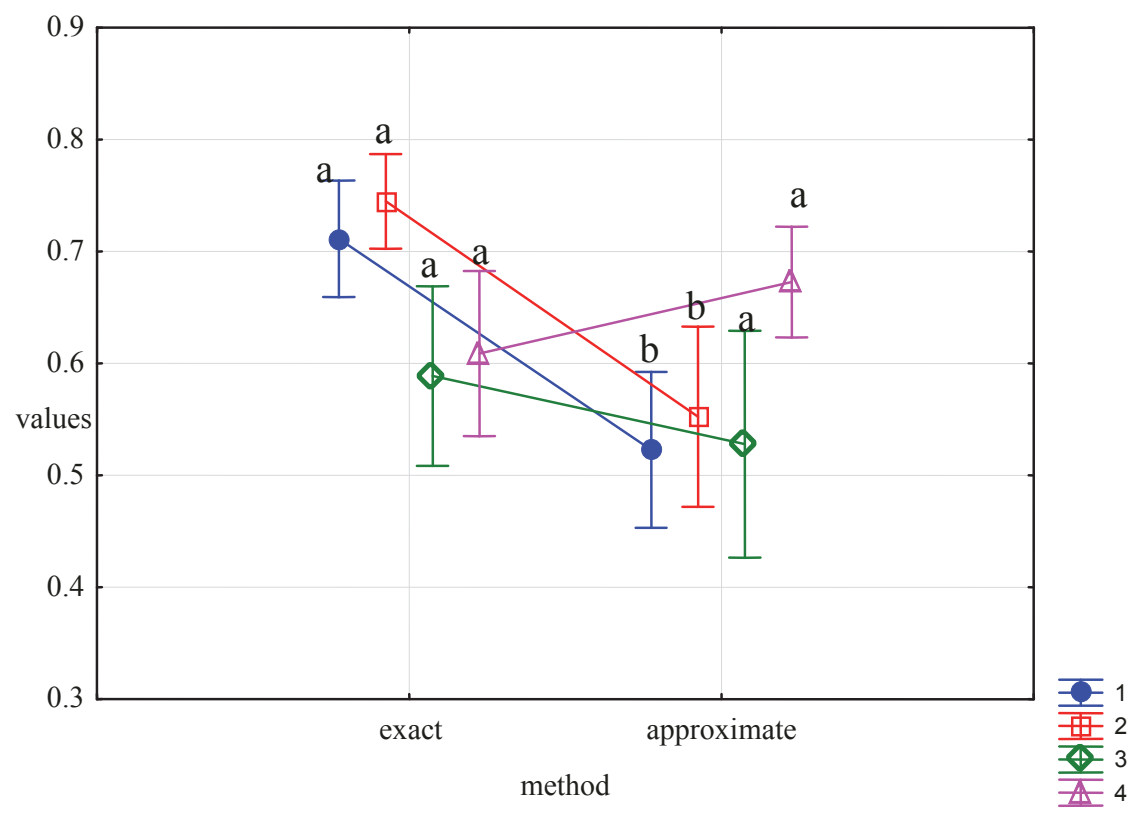

Explanations: 1 - potato crops, 2 - winter crops, 3 - spring crops, 4 - stubble fields, ab - significant at $\mathrm{p}<0.05$

Fig. 3. Simpson's indices of species richness (D) by calculation method and crop studies

Average values of index $\mathrm{H}^{\prime}$

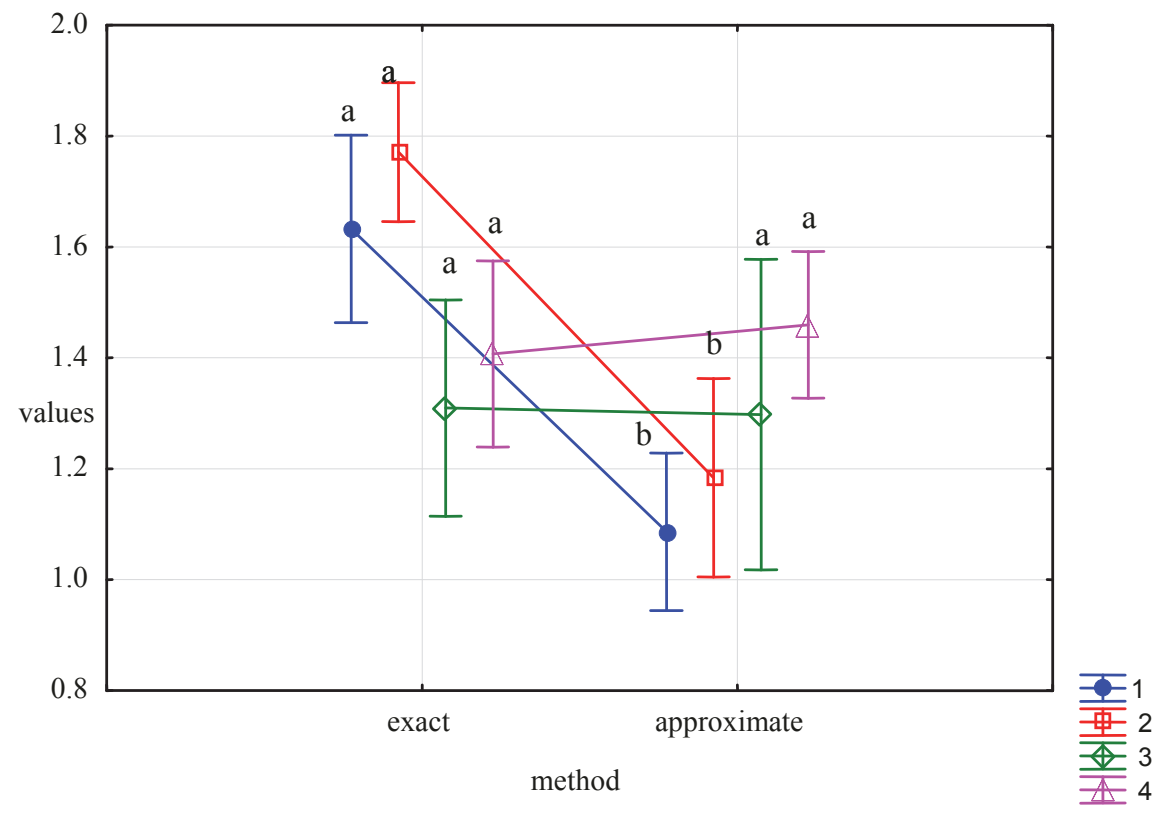

Explanations: 1 - potato crops, 2 - winter crops, 3 - spring crops, 4 - stubble fields, ab - significant at $\mathrm{p}<0.05$

Fig. 4. Shannon \& Weiner indices of biodiversity (H') by calculation method and crop studied

\section{DISCUSSION}

Various ecological indicators are used to evaluate biodiversity but it is vital to select them appropriately. In the literature on the subject, more and more authors seek the most suitable methods to assess the present state of communities studied $[2,15,16]$.
Weed communities that form in agricultural crops are also under constant human pressure, which results in quantitative and qualitative changes taking place inside them. To analyze these changes, it is necessary to perform a detailed assessment of agrocenoses and apply more and more precise methods to determine 
their condition. Ecological indices gain popularity in such analyses.

The species-number approach has been the most popular in such studies of biodiversity [8].

Biodiversity indices in agricultural studies have been used to analyze weed infestation and diaspore reserves in static experiments. They were usually calculated using the number of species or biomass [17-20]. According to many authors, biomass is the best measure of capturing differences in communities [21,22], but such studies are time-consuming and labor-intensive [23].

Studies to evaluate biodiversity in agricultural crops employing indices based on cover are much less frequent $[6,9,24,25]$. Cover is an easy measure but it is not always proportional to the energy used by individual species and does not fully reflect their richness [21,22]. Although the Braun-Blanquet approach is not reliable when cover is estimated in small areas, the method is suggested when larger areas are studied [4,5].

Experimental values of biodiversity indices reported in the literature range between 1.2 and 2.4 $[10,20]$, whereas those calculated based on cover have usually been lower, ranging from 1.0 to $2.0[6,25,26]$. Unfortunately, the indices cannot be compared directly, because they refer to different habitat and agrotechnological conditions.

The results of the study presented in this paper appear to support this assumption, as the values of the biodiversity index calculated based on the exact method were higher compared with the approximate approach. Such relationships were observed for winter cereals and tuber crops. Differences between the aforementioned values computed using the exact and approximate methods may arise from a rough assessment of cover for some ground species when using the approximate method. Plants of such species have small biomass and, although numerous, produce small cover. What is more, many species coexisting with tuber crops are characterized by large biomass and, as a result, just one plant produces large cover; due to this, the values of indices differ for both methods. Precise determination of cover based on the extended van der Maarel's scale [27] would probably eliminate this problem. Such differences were not found for spring cereals and stubble fields, which can result from smaller differences between sizes of individual weedy species.

\section{CONCLUSIONS}

A comparative analysis of the values of ecological indices calculated using the exact and approximate methods revealed significant differences between these approaches.
The calculated and compared values of the indices obtained for individual crops revealed significant differences for potato crops and winter cereals and insignificant differences for spring cereals and stubble fields.

A moderate correlation for the indices analyzed was determined for potato crops and winter cereals, whereas for spring cereals and stubble fields the correlation was weak or very weak.

\section{Acknowledgements}

Research supported by the Ministry of Science and Higher Education of Poland as part of the statutory activities of the Department of Agricultural Ecology, Siedlce University of Natural Sciencies and Humanities.

\section{Authors' contributions}

The following declarations about authors' contributions to the research have been made: concept of the study: MŁ, ZR; field work: MŁ, ZR; data analyses: MŁ, ZR; writing of the manuscript: MŁ, ZR.

\section{REFERENCES}

1. van Calster H, Vandenberghe R, Ruysen M, Verheyen K, Hermy M, Decocq G. Unexpectedly high 20th century floristic losses in a rural landscape in northern France: floristic changes in rural landscapes. J Ecol. 2008; 96(5): 927-936. http://dx.doi.org/10.1111/ j.1365-2745.2008.01412.x

2. Storkey J, Meyer S, Still KS, Leuschner C. The impact of agricultural intensification and land-use change on the European arable flora. Proc R Soc B. 2011; 279(1732): 1421-1429. http://dx.doi.org/10.1098/rspb.2011. 1686

3. Danilov RA, Ekelund NGA. Comparative studies on the usefulness of seven ecological indices for the marine coastal monitoring close to the shore on the Swedish east coast. Env Monit Assess. 2001; 66(3): 265-279. http://dx.doi. org/10.1023/A:1006364317956

4. Archaux F, Bergès L, Chevalier R. Are plant censuses carried out on small quadrats more reliable than on larger ones? Plant Ecol. 2006; 188(2): 179-190. http:// dx.doi.org/10.1007/s11258-006-9155-y

5. Lep̌s J, Hadincová V. How reliable are our vegetation analyses? J Veg Sci. 1992; 3(1): 119-124. http://dx.doi. org/10.2307/3236006

6. Skrzyczyńska J, Ługowska M. Dominacja gatunków i bioróżnorodność zbiorowisk agrocenoz ziemniaka Doliny Środkowej Wisły [Species domination and biodiversity in weed communities of agrocenoses of the Middle Vistula Valley]. Zesz Probl Post Nauk Rol. 2008; 530: 105-115. 
7. Rola H. Zjawisko konkurencji wśród roślin i jej skutki na przykładzie wybranych chwastów występujących w pszenicy ozimej. Puławy: Wyd IUNG; 1982; 162: 64.

8. Trzcińs k a-Ta cik H. Znaczenie różnorodności gatunkowej chwastów segetalnych [Importance of field weeds species diversity]. Pam Puł. 2003; 134: 263-262.

9. Stupnicka-Rodzynkiewicz E, Stępniak K, Dąbkowska T, Łabza T. Różnorodność zbiorowisk chwastów w uprawach zbóż w Beskidach [Diversity of cereal crops weed communities in the Beskidy Mountains]. Fragm Agron. 2004; 4(84): 45-54.

10. Fe ledy n-Szewczyk B, Duer I. Bioróżnorodność flory segetalnej w roślinach uprawianych w ekologicznym, integrowanym i konwencjonalnym systemie produkcji rolnej [Biodiversity of weed flora in crops cultivated in organic, integrated and conventional production systems]. Pam Pul. 2007; 145: 62-75.

11. Wanic M, Jastrzębska M, Kostrzewska MK, Nowicki J. Species domination in oats phytocenosis and its yield. Acta Agrobot. 2006; 59(2): 303-321. http://dx.doi. org/10.5586/aa.2006.085

12. Trąba C, Zi e mińska-S myk M. Różnorodność florystyczna chwastów w uprawach roślin okopowych otuliny Roztoczańskiego Parku Narodowego [Floristic diversity of weed communities in the root crops of the Roztocze National Park buffer zone]. Pam Puł. 2006; 143: 195-206.

13. Rzymowska Z, Ługowska M, Skrzyczyńska J. Species diversity of segetal communities in tuber crops and in winter and spring cereals. Acta Agrobot. 2013; 66(3): 95-102. http://dx.doi.org/10.5586/aa.2013.043

14. D z w on k o Z. Przewodnik do badań fitosocjologicznych [Guidebook to phytosociological studies]. Cracow: Instytut Botaniki Uniwersytetu Jagiellońskiego; 2007.

15. Van Strien AJ, Soldaat LL, Gregory RD. Desirable mathematical properties of indicators for biodiversity change. Ecol Indic. 2012; 14(1): 202-208. http://dx.doi. org/10.1016/j.ecolind.2011.07.007

16. Bandeira B, Jamet JL, Jamet D, Ginoux JM. Mathematical convergences of biodiversity indices. Ecol Indic. 2013; 29: 522-528. http://dx.doi.org/10.1016/j.ecolind. 2013.01.028

17. Pudełko J, Skrzypczak G, Maciejewski T. Zachwaszczenie kukurydzy uprawianej po ziemniakach i zbożach [Weed populations resulting from forecrop in maize]. Prog Plant Prot Post Ochr Roślin. 2006; 46(2): 210-214.

18. Feledyn-Szewczyk B, Duer I. Podobieństwo glebowego banku nasion i aktualnego zachwaszczenia łanu pszenicy ozimej w różnych systemach produkcji rolnej [Similarity between soil seed bank and current weed flora in winter wheat cultivated in different crop production systems]. Ann UMCS Sec E. 2007; 62(2): 157-167.

19. Jastrzębska M, Bogucka B, Hruszka M Następstwo roślin i proekologiczne sposoby regulacji zachwaszczenia a bioróżnorodność chwastów w bobiku [Crop sequence and environment-friendly weed control methods versus weed biodiversity in faba bean fields]. Acta Agrophys. $2007 ; 10(2)$ : 357-371.

20. Sekutowski T, Domaradzki K. Bioróżnorodność gatunkowa chwastów w monokulturze pszenicy ozimej w warunkach stosowania uproszczeń w uprawie roli [Biodiversity of weed species in winter wheat monoculture caused by reduced of tillage]. Fragm Agron. 2009; 26(4): 160-169.

21. Guo Q, Rundel PW. Measuring dominance and diversity in ecological communities: choosing the right variables. J Veg Sci. 1997; 8(3): 405-408. http://dx.doi.org/10. 2307/3237331

22. Chiarucci A, Wilson JB, Anderson BJ, De Dominicis V. Cover versus biomass as an estimate of species abundance: does it make a difference to the conclusions? J Veg Sci. 1999; 10(1): 35-42. http://dx.doi.org/10. $2307 / 3237158$

23. Wilson JB. Methods for fitting dominance/diversity curves. J Veg Sci. 1991; 2(1): 35-46. http://dx.doi.org/10. $2307 / 3235896$

24. Dąbkowska T, Stupnicka-Rodzynkiewicz E, Łabza T. Zachwaszczenie upraw zbóż w gospodarstwach ekologicznym, konwencjonalnym $\mathrm{i}$ intensywnym na wybranych przykładach z Małopolski [Weed infestation of cereals in organic, conventional and intensive farms in Małopolska region]. Pam Puł. 2007; 145: 5-16.

25. Skrzyczyńska J, Rzymowska Z, Pawlonka Z. Wpływ systemu gospodarowania na agrocenozy Wysoczyzny Siedleckiej [Effect of farming system on agrophytocenoses in the Siedlce Upland]. Fragm Agron. 2009; 4(96): 176-183.

26. Stosi k T. Stan i uwarunkowania ochrony różnorodności biologicznej w przestrzeni rolniczej obszaru o niskim potencjale produkcyjnym [State and conditions of the protection of biodiversity in agricultural area of low production potential]. Zesz Probl Post Nauk Rol. 2010; 556: 975-985.

27. Van der Ma arel E. Transformation of cover-abundance values for appropriate numerical treatment - alternatives to the proposals by Podani. J Veg Sci. 2007; 18(5): 767-770. http://dx.doi.org/10.1111/j.1654-1103.2007.tb02592.x

\section{Wpływ zastosowania metody ścisłej i szacunkowej na wartość wybranych wskaźników ekologicznych}

\section{Streszczenie}

W pracy przedstawiono wyniki badań dotyczące bioróżnorodności agrocenoz z wykorzystaniem wskaźników ekologicznych. Do wyliczenia wskaźników posłużyły zdjęcia fitosocjologiczne i badania ścisłe wykonane w uprawach zbóż ozimych, jarych i okopowych oraz na ściernisku. Celem pracy było porównanie wskaźników ekologicznych (dominacji Simpsona C, bogactwa gatunkowego Simpsona D i bioróżnorodności Shannona\&Weinera H') wyliczonych na podstawie 
liczebności i pokrycia gatunków. Ponadto wykonano analizę korelacji badanych wskaźników liczonych w oparciu o porównywane metody.

Na podstawie otrzymanych wyników stwierdzono istotne różnice wszystkich analizowanych wskaźni- ków liczonych w oparciu o metodę ścisłą i szacunkową. Natomiast porównując te wskaźniki w poszczególnych uprawach stwierdzono istotne różnice dla okopowych i zbóż ozimych, natomiast w zbożach jarych i na ścierniskach takiej zależności nie ma.

Handling Editor: Elżbieta Weryszko-Chmielewska

This is an Open Access digital version of the article distributed under the terms of the Creative Commons Attribution 3.0 License (creativecommons.org/licenses/by/3.0/), which permits redistribution, commercial and non-commercial, provided that the article is properly cited.

CThe Author(s) 2014 Published by Polish Botanical Society 